\title{
DFT Study on the Mechanism of DNA Damage Caused by the Isomerization of DNA Purine Base
}

\author{
Jun Shao (Corresponding author) \\ Department of Basic, Heze Medical College \\ Heze 274015, China \\ Tel: 86-530-5925960_E-mail: shaoj-08@163.com \\ Xianjie Lin \\ Department of Chemistry and Chemical Engineering, Heze University \\ Heze 274030, China \\ Tel: 86-530-566-8069_E-mail: linxianjie@sina.com
}

Received: March 18, 2011 Accepted: March 31, 2011 doi:10.5539/ijc.v3n3p44

\begin{abstract}
The mechanism of DNA damage caused by the isomerization of purine base is studied with DFT method at the B3LYP/6-311G** level. Among the three isomers of adenine and eight isomers of guanine, the normal configurations in DNA Watson-Crick base pairs are the most stable isomers. The transition states of all the isomerizations are obtained, and the IRC analyses are performed to identify these transition states further. The isomerizations of purine bases can be classified into two types, the hydrogen transfer between atoms and the hydrogen swing of imino. The former's transition states include a four-ring, which is coplanar with the purine base backbone. The latter's transition states involve a three-atom ' $\mathrm{V}$ ' structure of $\mathrm{C}=\mathrm{N}-\mathrm{H}$, and the plane of $\mathrm{C}=\mathrm{N}-\mathrm{H}$ is perpendicular to that of the purine base backbone. The isomerizations, which result in the normal configuration changes of purine base and bring directly the DNA damage, belong to the hydrogen transfer process, and they are endothermic and thermodynamic non-spontaneous process. The probability of DNA damage caused by the guanine isomerization is larger than that by adenine.
\end{abstract}

Keywords: DNA damage, Adenine, Guanine, Isomerization, DFT

\section{Introduction}

DNA damage takes place at any moment in the living organism. Most of the damages can be repaired by the repair system of the organism itself. The unrepaired damage can lead to gene mutation, induce cancer and other diseases related to gene, influence the growth of cell and even make directly cell die (Olinski, 2002, p192; Slupphaug, 2003, p231; Crow, 1997, p8380). On the other hand, DNA damage is a necessary condition of organism evolution, and the DNA damage induced artificially may be used to cure diseases, improve and create species(Uromo, 1999, p1091; Staub, 2000, p333). Among various factors bringing DNA damage within and without organism, the isomerization of base is an important one (Rogozin, 2003, p65; Burney, 1999, p37). Recently, many biological and chemical methods have been used to detect DNA damage (Vigreux, 1998, p79; Nishisho, 1991, p665), and some damage sites of DNA have been determined. But the DNA damage mechanism, especially the mechanism at the molecular level, is still unclear (Durbeej, 2002, p95; Matsuda, 2001, p335). There are two kinds of bases, pyrimidine base and purine base, in the normal structure of DNA. In this paper, the DNA damage mechanism caused by the purine base isomerization is investigated with DFT (Density Functional Theory) method at the B3LYP/6-311G** level. The thermodynamic and kinetic properties of the isomerizations of purine base are discussed, too.

\section{Models and Methods}

\subsection{Models of isomerizations}

The isomerization of base takes place mainly in the single-stranded DNA. In the processes of the semiconservative replication and the abnormal unwinding, DNA is single-stranded. The DNA in telomere end 
and some virus is also the single-stranded. Besides, the single-stranded DNA is widely used in gene engineering. The base isomerization is affected by many factors, including the solvation, the action of various ions and so on. However, the research of the self-isomerization of the bases is the foundation for the further investigation. So our research focuses on the self-isomerization of single-stranded DNA base.

The purine base, adenine (ADE) and guanine (GUA), link to ribose backbone though the glycosidic bond. Because the ribose backbone have little influence on the base isomerization (Cysewski, 1998, p219), the free base model is chosen by breaking the glycosidic bond and saturating it with $\mathrm{H}$ atoms (marked as $\mathrm{H}^{*}$ ). The isomers and isomerization processes of purine base are shown in Fig. 1.

\subsection{Computational method}

The geometry optimizations of the isomers and the transition states are performed with DFT method at the B3LYP/6-311G** level. To identify the transition states of the isomerizations, the IRC (Intrinsic Reaction Coordinate) calculations (Gonzalez, 1990, p5523) are carried out for all the isomerizations. All calculations are completed with the Guassian 98 program. The zero point energy correction is considered in our calculations.

The activation energy (E), pre-exponential factor (A) and rate constant (k) of the isomerizations are obtained according to the classical transition state theory. The enthalpy change $(\Delta \mathrm{H})$, entropy change $(\Delta \mathrm{S})$, Gibbs free energy change $(\Delta \mathrm{G})$ and equilibrium constant $\left(\mathrm{K}_{\mathrm{P}}\right)$ are calculated by the statistic thermodynamics method based on the results of DFT calculation (Sun, 1998, p361; Ma, 1996, p777) If we write the maximum isomerization ratio (i.e. maximum convert ratio) of reactant to product as

$r_{\mathrm{R} \rightarrow \mathrm{P}}$, we have

$$
r_{R \rightarrow P}=\frac{n_{P}}{n_{P}+n_{R}}=\frac{K_{P}}{K_{P}+1}
$$

for unimolecular isomerization reaction. Here $n_{\mathrm{P}}, n_{\mathrm{R}}$ and $K_{P}$ are product molecular number, reactant molecular number and equilibrium constant respectively. This means that $r_{\mathrm{R} \rightarrow \mathrm{P}}$ can be calculated according to the equilibrium constant of the isomerization. The normal body temperature of human is about $310 \mathrm{~K}\left(37^{\circ} \mathrm{C}\right)$, and the live environmental temperature range is about $220 \sim 320 \mathrm{~K}\left(-50 \sim+50{ }^{\circ} \mathrm{C}\right)$. Other organisms have the similar body temperature and the live environmental temperature range to human. So the calculation temperature range of thermodynamic and kinetic properties is chosen as $220 \mathrm{~K} \sim 320 \mathrm{~K}$.

\section{Results and Discussion}

\subsection{Mechanism and kinetic properties}

\subsubsection{Isomerization mechanism}

Adenine has three kinds of isomers, which are marked as ADE1, ADE2 and ADE3 respectively. Their isomers and isomerization reactions have been shown in Fig.1. In the process of ADE1 $\rightarrow$ ADE2, H12 transfers from $\mathrm{N} 10$ to N1. It belongs to the hydrogen transfer between atoms. The process of ADE2 $\rightarrow$ ADE3 is the hydrogen swing of imino. Guanine has eight kinds of isomers, which are marked as GUA1, GUA2 GUA3, GUA4, GUA5, GUA6, GUA7 and GUA8 respectively. Their isomers and isomerization reactions have been shown in Fig.1, too. In the processes of GUA1 $\rightarrow$ GUA2, GUA3 $\rightarrow$ GUA5 and GUA3 $\rightarrow$ GUA7, the hydrogen atom transfers between two $\mathrm{N}$ atoms. While GUA1 $\rightarrow$ GUA3, the hydrogen atom transfers from $\mathrm{N}$ atom to $\mathrm{O}$ atom. The processes of GUA2 $\rightarrow$ GUA4, GUA5 $\rightarrow$ GUA6, GUA7 $\rightarrow$ GUA8 belong to the hydrogen swing of imino.

The transition states of all the above-mentioned isomerizations have been obtained. The imaginary frequencies, geometries and charge populations of the chief part of the transition states are shown in Fig.2 respectively. All of the transition states of the hydrogen transfer include a four-ring, which is coplanar with the backbone of the purine base. In all the transition states of the hydrogen swing, $\mathrm{C}=\mathrm{N}-\mathrm{H}$ has a structure of ' $\mathrm{V}$ ' type, and its plane is perpendicular to the backbone plane of the purine base. To compare the structure and the charge population of transition state with that of the reactant, the geometries of all isomers of adenine and guanine are shown in Fig. 3, and the charge populations and geometries parameters of their chief parts are listed in Tables $1 \sim 2$.

The transition state of ADE1 $\rightarrow$ ADE2 is marked as TS-A12 (the other transition states are marked in the similar way as that of ADE1 $\rightarrow$ ADE2). By comparing TS-A12 with ADE1, the angle C6-N10-H12 decreases from $119.2^{\circ}$ to $76.0^{\circ}$, the $\mathrm{N} 10-\mathrm{H} 12$ bond length increases from 0.101 to $0.140 \mathrm{~nm}$, and the electron population between $\mathrm{N} 10$ and $\mathrm{H} 12$ decreases from 0.319 to 0.135 . This shows that the N10-H12 bond is weakened greatly. According to the distance $(0.132 \mathrm{~nm})$ and the electron population $(0.116)$ between $\mathrm{N} 1$ and H12, we can see that 
theN1-H12 bond is forming. The decrease of distance and the increase of electron population between C6 and N10 also indicate that the double bond of C6-N10 is forming. Similarly, it can be seen that the C6-N1 double bond is changing to the single bond. In addition, the differences of the charge distribution between ADE1 and TS-A12 can be observed.

The process of ADE $2 \rightarrow$ ADE3 belongs to hydrogen swing of imino. The main differences between ADE2 and TS-A23 are in two aspects, the angle C6-N10-H11 and the plane of C6-N10-H12. The former changes from $109.1^{\circ}$ to $143.5^{\circ}$, and the latter changes from being coplanar with the adenine backbone to being perpendicular to it. The electron population between $\mathrm{C} 6$ and N10 changes from 0.643 (in ADE2) to 0.521 (in TS-A23), so the C6-N10 bond becomes weak obviously. The strength of N10-H11 bond increases slightly. The charge of C6 is 0.476 in reactant ADE2, and it increases to 0.602 in TS-A23. At the same time, the charge of N10 decreases from -0.667 to -0.802 . So the charge transfer from $\mathrm{C} 6$ to N10 has taken place.

The guanine has seven isomerization reactions. The processes of GUA1 $\rightarrow$ GUA2, GUA1 $\rightarrow$ GUA3, GUA3 $\rightarrow$ GUA5 and GUA3 $\rightarrow$ GUA7 are the hydrogen transfer, in which the hydrogen atom transfers from $\mathrm{N}$ to $\mathrm{N}$ or to $\mathrm{O}$, and the processes of GUA2 $\rightarrow$ GUA4, GUA51 $\rightarrow$ GUA6 and GUA7 $\rightarrow$ GUA8 are the hydrogen swing of imino. As for the hydrogen transfer of guanine, the reaction behaviors, such as the change of bond and charge population, are similar to that of the ADE1 $\rightarrow$ ADE2. Analogously, the hydrogen swing of guanine is similar to that of adenine.

\subsubsection{Kinetic properties}

The activation energies of the isomerizations of adenine and guanine are shown in Fig.4. We can find that the activation energies of the hydrogen transfer between $\mathrm{N}$ atoms (E-A12, E-G12, E-G13, E-G35 and E-G37) are higher than that of the hydrogen transfer from $\mathrm{N}$ atom to $\mathrm{O}$ atom (E-G13). The activation energies of all the hydrogen transfers are higher than that of the hydrogen swing of imino (E-A23, E-G24, E-G56, and E-G78). It is well known that the activation energy, which is also called reaction potential barrier, is a descriptor of the reaction. The low activation energy implicates that the reaction is easy to carry out. So the hydrogen swing should take place more easily than the hydrogen transfer. The imaginary frequencies of all transition states are also shown in Fig. 2. We can find that the imaginary frequencies of hydrogen transfer transition states are all about 2000, however, that of hydrogen swing transition states are all about 1000. The former is almost the double of the latter, so the quantum tunnel effect of hydrogen transfer is larger than that of hydrogen swing (Ma, 1996, p777).

The lowest energy reaction paths of the isomerizations of adenine and guanine traced by IRC calculations are shown in Fig. 5. Starting from the transition state, the reactant and the product can be reached separately along the lowest reaction path for every isomerization process. This shows that the identifications of the above transition states are correct. All of the isomerizations of purine base are unimolecule elementary reaction, so their rate equations must have the characters of the first order reaction. The rate constants $(\mathrm{k})$ and the pre-exponent factors (A) of all isomerizations of adenine and guanine are list in Tables 3 11 respectively. The pre-exponent factors (A) of the isomerizations of adenine and guanine are about $10^{13}$, which are consistent with the theoretical and experimental result of unimolecular reaction (Steinfeld, 1999, p16).

Tables 3 11 show that the rate constants of hydrogen transfer are smaller than that of hydrogen swing, and the rate constants of hydrogen transfer from $\mathrm{N}$ atom to $\mathrm{N}$ atom are smaller than that from $\mathrm{N}$ atom to $\mathrm{O}$ atom. ADE1 and GUA1 are the normal configurations of adenine and guanine in DNA Watson-Crick base pairs. The isomerizations ADE1 $\rightarrow$ ADE2, GUA1 $\rightarrow$ GUA2 and GUA1 $\rightarrow$ GUA3, which would result in the normal configuration change of purine base and bring directly DNA damage, have the small rate constants. That is to say, DNA damage caused by the isomerizations of purine base is very slow.

Human body has about $10^{14}$ cell, and each cell contains about $4 \times 10^{9}$ base. If we presume that the numbers of the four kind of bases are equal to each other in body, the numbers of adenine and guanine are all about $10^{23}$ or $1 \mathrm{~mol}$. The concentration of adenine or guanine is about $10^{21} / \mathrm{L}$ or $0.02 \mathrm{~mol} / \mathrm{L}$ after taking the volume of human body as $50 \mathrm{~L}$. According to the rate equation of the first order reaction $\mathrm{v}=\mathrm{kC}$, we can figure out that the damage rate caused by the adenine isomerization in human body is about $10^{-11} \mathrm{~s}^{-1}(220 \mathrm{~K}) \sim 10^{2} \mathrm{~s}^{-1}(320 \mathrm{~K})$. In the parallel reactions of GUA1 $\rightarrow$ GUA2 and GUA1 $\rightarrow$ GUA3, the GUA1 $\rightarrow$ GUA3 with larger rate constant would determine the total isomerization rate of guanine. So the DNA damage rate caused by the guanine isomerization is determined by the rate of GUA1 $\rightarrow$ GUA3. Similarly, we can figure out that the damage rate via the guanine isomerization in human body is about $1 \mathrm{~s}^{-1}(220 \mathrm{~K}) \sim 10^{11} \mathrm{~s}^{-1}(320 \mathrm{~K})$. Obviously, the probability of DNA damage caused by guanine isomerization should be much bigger than that caused by adenine. 


\subsection{Thermodynamic properties}

The energies of all isomers shown in Fig. 6 and Fig. 7 indicate that the normal configurations, ADE1 and GUA1, are the most stable among all of the isomers of adenine and guanine respectively. The thermodynamic properties of the adenine isomerizations listed in Table 3 and Table 4 show that the entropy changes for two isomerizations of adenine are negative (i.e. $\Delta \mathrm{S}<0)$. The isomerization ADE1 $\rightarrow$ ADE2 is an endothermic reaction $(\Delta \mathrm{H}>0)$, and its Gibbs free energy change is positive $(\Delta \mathrm{G}>0)$, so the isomerization ADE1 $\rightarrow$ ADE2 is a thermodynamic non-spontaneous process. We can calculate out that $\mathrm{r}_{\mathrm{ADE} 1 \rightarrow \mathrm{ADE} 2}=10^{-12}$ according to the equilibrium constant at the $310 \mathrm{~K}$. Namely, the isomerization ratio of adenine is very small. The process of ADE2 $\rightarrow$ ADE3 has negative $\Delta \mathrm{H}, \Delta \mathrm{S}$ and $\Delta \mathrm{G}$, so it is exothermic and thermodynamic spontaneous process. The isomerization ratio $\mathrm{r}_{\mathrm{ADE} 2 \rightarrow \mathrm{ADE} 3} \approx 1$ in the range of $220 \mathrm{~K} \sim 320 \mathrm{~K}$, that is to say, the most of ADE2 can be transformed into ADE3.

The thermodynamic data of the isomerizations of guanine are listed in Tables $5 \sim 11$. The processes of GUA1 $\rightarrow$ GUA3 and GUA5 $\rightarrow$ GUA6 have entropy change $\Delta \mathrm{S}<0$, and the others have $\Delta \mathrm{S}>0$. The isomerization GUA5 $\rightarrow$ GUA6 is an exothermic reaction $(\Delta \mathrm{H}<0)$, and the others are the endothermic reactions $(\Delta \mathrm{H}>0)$. According to the value of $\Delta \mathrm{G}$, GUA5 $\rightarrow$ GUA6 is a thermodynamic spontaneous process, but the others are the non-spontaneous processes. The isomerization ratios of GUA1 to GUA2 and GUA3 at $310 \mathrm{~K}$ are $\mathrm{r}_{\mathrm{GUA} 1 \rightarrow \mathrm{GUA} 2}=10^{-9}$ and $\mathrm{r}_{\mathrm{GUA} 1 \rightarrow \mathrm{GUA} 3}=10^{-2}$, which are calculated according to the equilibrium constants of the isomerizations. It is shown that GAU1 is transformed mainly to GUA3. Comparing $\mathrm{r}_{\mathrm{GUA} 1 \rightarrow \mathrm{GUA3}}=10^{-2}$ with $\mathrm{r}_{\mathrm{ADE} 1 \rightarrow \mathrm{ADE} 2}=10^{-12}$, we find that the isomerization ratio of GUA1 is much bigger than that of ADE1. This means that the probability of DNA damage caused by the isomerization of guanine should be bigger than that by adenine.

\section{Conclusions}

The normal configurations, ADE1 and GUA1, are the most stable isomer among the three isomers of adenine and eight isomers of guanine, respectively. All of the isomerizations of purine base are unimolecule elementary reaction, and they can be divided into two types, the hydrogen transfer between atoms and the hydrogen swing of imino. All the transition states of hydrogen transfer have a four-ring which is coplanar with the purine base backbone. In the transition states of hydrogen swing of imino, $\mathrm{C}=\mathrm{N}-\mathrm{H}$ is in ' $\mathrm{V}$ ' type, and the plane of $\mathrm{C}=\mathrm{N}-\mathrm{H}$ is perpendicularity to that of the purine base backbone. In all of the transition states, the geometries and the charge distributions are changed comparing with those of the corresponding reactants. The isomerization rates and ratios of guanine are larger than those of adenine. In other words, the probability of DNA damage at guanine sites is larger than that at adenine sites. The isomerizations ADE1 $\rightarrow$ ADE2, GUA1 $\rightarrow$ GUA2 and GUA1 $\rightarrow$ GUA3, which result in the normal configuration changes of purine base and bring directly DNA damage, belong to the hydrogen transfer process, and they are endothermic and thermodynamic non-spontaneous process.

\section{References}

Burney, S., Caulfield, J. L., Niles, J. C., Wishnok, J. S. \& Tannenbaum, S. R. (1999). The chemistry of DNA damage from nitric oxide and peroxynitrite. Mutat. Res. 424, 37-49.

Crow, J. F. (1997). The high spontaneous mutation rate: Is it a health risk? Proc. Natl. Acad. Sci. USA, 94, 8380-8386.

Cysewski, P. \& Jeziorek, D. (1998). An ab inito study on the tautomerisation of the 8-oxo-guanine and xanthine. J. of Molecular Structure (Theochem), 430, 219-229.

Durbeej, B. \& Eriksson, L. A. (2002). Reaction mechanism of thymine dimer formation in DNA induced by UV light, J. Photochem. Photobiol. A, 152, 95-101.

Gonzalez, C. \& Schlegel, H. B. (1990). Reaction path following in mass-weighted internal coordinates. J. Phys.Chem., 94, 5523.

Ma, A., Sun, L.,Wang, Y., Liu, C. \& Deng, C. (1996). Theory study of the decompositions of $\mathrm{CF}_{3} \mathrm{CO}$ and $\mathrm{CF}_{3} \mathrm{C}(\mathrm{O}) \mathrm{O}$ radicals. Chem. J. Chin. Univ., 17, 777.

Matsuda, T., Bebenek, K., Masutani, C., Rogozin, I. B., Hanaoka, F. \& Kunkel, T. A. (2001). Error rate and specificity of human and murine DNA polymerase eta. J. Mol. Biol., 312, 335-346.

Nishisho, I., Nakamura, Y., Miyoshi, Y., Mik,i Y., Ando, H., Horii, A., Koyama, K., Utsunomiya, J., Baba, S. \& Hedge, P. (1991). Mutations of chromosome 5q21 genes in FAP and colorectal cancer patients. Science, 253, 665-670.

Olinski, R., Gackowski, D., Foksinski, M., Rozalski, R., Roszkowski, K. \& Jaruga, P. (2002). Oxidative DNA damage: assessment of the role in carcinogenesis, atherosclerosis, and acquired immunodeficiency syndrome. 
Free Radic Biol. Med., 33,192.

Rogozin, I. B. \& Pavlov, Y. I. (2003). Theoretical analysis of mutation hotspots and their DNA sequence context specificity. Mutat. Res., 544, 65-85.

Slupphaug, G., Kavli, B. \& Krokan, H. E. (2003). The interacting pathways for prevention and repair of oxidative DNA damage. Mutat. Res., 531: 231-251.

Staub, J. M. (2000). High-yield production of a human therapeutic protein in tobacco chloroplasts. Nat. Biotechnol., 18, 333-338.

Steinfeld, J. I., Francisco, J. S. \& Hase W. L. (1999). Chemical Kinetics and Dynamics. Prentice Hall

Sun, L., Ma, A., Wang, Y. \& Liu, C. (1996). Thermodynamic and kinetic study of gas-phase hydrolysis of $\mathrm{CF}_{3} \mathrm{C}(\mathrm{O}) \mathrm{F}$ to $\mathrm{CF}_{3} \mathrm{COOH}$. Acta Phys-Chim. Sin., 16, 361.

Uromo, A. R. H. (1999). Temporal, spatial, and cell type-specific control of Cre-mediated DNA recombination in transgenic mice. Nat. Biotechnol., 17, 1091-1096.

Vigreux, C., Doul J. M. \& Deslandes, E. (1998). DNA damaging effects of pesticides measured by the single cell gel electrophoresis assay (comet assay) and the chromosomal aberration test in CHOK1 cells. Muta. Res., 419, 79-90.

Table 1. The charges, electron populations and geometry parameters of the main parts of three adenine isomers

\begin{tabular}{|c|c|c|c|c|}
\hline & & ADE1 & ADE2 & ADE3 \\
\hline \multirow{4}{*}{ Charge } & $\mathrm{N} 1$ & -0.512 & -0.617 & -0.627 \\
\cline { 2 - 5 } & $\mathrm{C} 6$ & 0.502 & 0.476 & 0.492 \\
\cline { 2 - 5 } & $\mathrm{N} 10$ & -0.787 & -0.667 & -0.653 \\
\cline { 2 - 5 } & $\mathrm{H} 11$ & 0.357 & 0.304 & 0.261 \\
\cline { 2 - 5 } & $\mathrm{H} 12$ & 0.347 & 0.348 & 0.332 \\
\hline & $\mathrm{C} 6-\mathrm{N} 10$ & $0.135(0.306)$ & $0.128(0.643)$ & $0.128(0.604)$ \\
\hline & $\mathrm{C6}-\mathrm{N} 1$ & $0.135(0.475)$ & $0.142(0.242)$ & $0.143(0.188)$ \\
\hline Bond length & $\mathrm{N} 10-\mathrm{H} 11$ & $0.101(0.297)$ & $0.102(0.311)$ & $0.102(0.269)$ \\
\hline (Electron population) & $\mathrm{N} 10-\mathrm{H} 12$ & $0.101(0.319)$ & - & - \\
\hline & $\mathrm{N} 1-\mathrm{C} 2$ & $0.134(0.460)$ & $0.136(0.334)$ & $0.137(0.294)$ \\
\hline & $\mathrm{N} 1-\mathrm{H} 12$ & - & $0.101(0.279)$ & $0.101(0.289)$ \\
\hline Bond angle & $\mathrm{C} 6-\mathrm{N} 10-\mathrm{H} 11$ & 120.4 & 109.1 & 111.7 \\
\hline & $\mathrm{C} 6-\mathrm{N} 10-\mathrm{H} 12$ & 119.2 & - & - \\
\hline & $\mathrm{C6}-\mathrm{N} 1-\mathrm{H} 12$ & - & 114.3 & 116.3 \\
\hline Dihedral angle & $\mathrm{N} 1-\mathrm{C6}-\mathrm{N} 10-\mathrm{H} 11$ & 180.0 & 180.0 & 180.0 \\
\hline & $\mathrm{N} 10-\mathrm{C} 6-\mathrm{N} 1-\mathrm{H} 12$ & 0.0 & 0.0 & 0.0 \\
\hline
\end{tabular}

Bond length: nm; Bond angle and dihedral angle: ${ }^{\circ}$ 
Table 2. The charges, electron populations and geometry parameters of the main parts of eight guanine isomers

\begin{tabular}{|c|c|c|c|c|c|c|c|c|c|}
\hline & & GUA1 & GUA2 & GUA3 & GUA4 & GUA5 & GUA6 & GUA7 & GUA8 \\
\hline \multirow{11}{*}{ Charge } & N1 & -0.697 & -0.730 & -0.581 & -0.703 & -0.718 & -0.692 & -0.587 & -0.552 \\
\hline & C6 & 0.577 & 0.608 & 0.501 & 0.615 & 0.566 & 0.580 & 0.524 & 0.523 \\
\hline & N10 & -0.772 & -0.661 & -0.764 & -0.647 & -0.643 & -0.699 & -0.676 & -0.624 \\
\hline & H11 & 0.351 & 0.347 & 0.338 & 0.333 & 0.251 & 0.290 & 0.340 & 0.324 \\
\hline & H12 & 0.334 & 0.284 & 0.337 & 0.273 & 0.320 & 0.341 & 0.291 & 0.255 \\
\hline & O14 & -0.502 & -0.489 & -0.595 & -0.488 & -0.581 & -0.581 & -0.587 & -0.589 \\
\hline & H13 & 0.339 & 0.341 & 0.412 & 0.358 & 0.418 & 0.421 & 0.416 & 0.418 \\
\hline & $\mathrm{C} 2$ & 0.707 & 0.698 & 0.618 & 0.694 & 0.615 & 0.609 & 0.610 & 0.606 \\
\hline & N3 & -0.580 & -0.746 & -0.569 & -0.771 & -0.552 & -0.582 & -0.730 & -0.753 \\
\hline & C6-O14 & $\begin{array}{c}0.122 \\
(0.627)\end{array}$ & $\begin{array}{c}0.122 \\
(0.621)\end{array}$ & $\begin{array}{c}0.134 \\
0308)\end{array}$ & $\begin{array}{l}0.122 \\
0622\end{array}$ & 0.134 & 0.134 & $\begin{array}{c}0.134 \\
0302\end{array}$ & $\begin{array}{c}0.134 \\
0303\end{array}$ \\
\hline & C6-N1 & 0.144 & 1.43 & 0.133 & 0.142 & 0.137 & 0.136 & 0.131 & 0.130 \\
\hline & & $(0.196)$ & $(0.183)$ & $(0.450)$ & $(0.213)$ & $(0.274)$ & $(0.306)$ & $(0.450)$ & $(0.46$ \\
\hline & $\mathrm{N} 1-\mathrm{C} 2$ & 0.137 & 0.140 & 0.136 & 0.139 & 0.146 & 0.144 & 0.139 & 0.139 \\
\hline & & $(0.299)$ & $(0.240)$ & $(0.438)$ & $(0.251)$ & $(0.188)$ & $(0.206)$ & $(0.350)$ & $(0.33$ \\
\hline & $\mathrm{C} 2-\mathrm{N} 3$ & 0.131 & 0.140 & 0.134 & 0.141 & 0.138 & 0.138 & 0.142 & 0.144 \\
\hline & & $(0.563)$ & $(0.273)$ & $(0.486)$ & $(0.257)$ & $(0.372)$ & $(0.391)$ & $(0.238)$ & $(0.22$ \\
\hline & C2-N10 & 0.138 & 0.128 & 0.137 & 0.128 & 0.128 & 0.128 & 0.128 & 0.128 \\
\hline & & $(0.336)$ & $(0.654)$ & $(0.332)$ & $(0.651)$ & $(0.614)$ & $(0.633)$ & $(0.634)$ & $(0.61)$ \\
\hline & N1-H13 & $\begin{array}{c}0.101 \\
(0.269 \\
\end{array}$ & $\begin{array}{c}0.101 \\
(0.283) \\
\end{array}$ & - & $\begin{array}{l}0.101 \\
(0.277) \\
\end{array}$ & - & - & - & - \\
\hline & N1-H12 & - & - & - & - & $\begin{array}{c}0.101 \\
(0.278)\end{array}$ & $\begin{array}{c}0.101 \\
(0.272)\end{array}$ & - & - \\
\hline Bond length & N10-H11 & $\begin{array}{c}0.101 \\
(0.304)\end{array}$ & - & $\begin{array}{c}0.101 \\
(0.303)\end{array}$ & - & $\begin{array}{c}0.102 \\
(0.265\end{array}$ & $\begin{array}{l}0.102 \\
(0.296)\end{array}$ & - & - \\
\hline \multirow[t]{5}{*}{ (Electron population) } & $\mathrm{N} 10-\mathrm{H} 12$ & $\begin{array}{c}0.101 \\
(0.306)\end{array}$ & $\begin{array}{l}0.102 \\
(0.294)\end{array}$ & $\begin{array}{c}0.101 \\
(0.303)\end{array}$ & $\begin{array}{l}0.102 \\
(0.285)\end{array}$ & - & - & $\begin{array}{c}0.102 \\
(0.294)\end{array}$ & $\begin{array}{c}0.102 \\
(0.265)\end{array}$ \\
\hline & N3-H11 & - & $\begin{array}{c}0.101 \\
(0.300)\end{array}$ & - & $\begin{array}{c}0.101 \\
(0.311)\end{array}$ & - & - & $\begin{array}{c}0.101 \\
(0.289)\end{array}$ & $\begin{array}{l}0.101 \\
(0.294)\end{array}$ \\
\hline & O14-H13 & - & - & $\begin{array}{c}0.098 \\
(0.229)\end{array}$ & - & $\begin{array}{c}0.097 \\
(0.236)\end{array}$ & $\begin{array}{c}0.097 \\
(0.237)\end{array}$ & $\begin{array}{l}0.098 \\
(0.229)\end{array}$ & $\begin{array}{l}0.098 \\
(0.228)\end{array}$ \\
\hline & C6-O14-H13 & - & - & 105.8 & - & 111.4 & 111.1 & 105.7 & 105.4 \\
\hline & C6-N1-H12 & 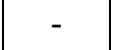 & - & - & - & 118.8 & 121.6 & - & - \\
\hline \multirow[t]{3}{*}{ Bond angle } & C6-N1-H13 & 113.3 & 113.0 & - & 115.2 & - & - & - & - \\
\hline & C2-N10-H11 & 112.5 & - & 116.0 & - & 112.0 & 108.5 & - & - \\
\hline & C2-N10-H12 & 117.1 & 111.8 & 116.2 & 112.1 & - & - & 108.7 & 111.3 \\
\hline \multirow{3}{*}{ Dihedral angle } & N1-C6-O14-H13 & - & - & 0.5 & - & 0.0 & 0.0 & 0.0 & 0.0 \\
\hline & N1-C2-N10-H12 & 169.8 & 0.0 & 163.0 & 180.0 & - & - & 180.0 & 180.0 \\
\hline & N1-C2-N10-H11 & 35.7 & - & 19.7 & - & 0.0 & 180.0 & - & - \\
\hline
\end{tabular}

Bond length: $\mathrm{nm}$; Bond angle and Dihedral angle: ${ }^{\circ}$. 
Table 3. Thermodynamic and kinetic properties of ADE1 $\rightarrow$ ADE2

\begin{tabular}{|ccccccc|}
\hline $\mathrm{T}(\mathrm{K})$ & $\triangle \mathrm{S}(\mathrm{J} / \mathrm{K} . \mathrm{mol}) \triangle \mathrm{H}(\mathrm{J} / \mathrm{mol})$ & $\triangle \mathrm{G}(\mathrm{J} / \mathrm{mol})$ & $\mathrm{K}_{\mathrm{P}}$ & $\log _{10}(\mathrm{~A})$ & $\mathrm{k}$ \\
\hline 220 & -1.613 & $7.7811 \mathrm{E}+04$ & $7.817 \mathrm{E}+04$ & $2.757 \mathrm{E}-19$ & 12.943 & $2.7 \mathrm{E}-33$ \\
230 & -1.780 & $7.778 \mathrm{E}+04$ & $7.819 \mathrm{E}+04$ & $1.752 \mathrm{E}-18$ & 12.950 & $2.6 \mathrm{E}-31$ \\
240 & -1.927 & $7.774 \mathrm{E}+04$ & $7.821 \mathrm{E}+04$ & $9.534 \mathrm{E}-18$ & 12.956 & $1.7 \mathrm{E}-29$ \\
250 & -2.082 & $7.771 \mathrm{E}+04$ & $7.822 \mathrm{E}+04$ & $4.528 \mathrm{E}-17$ & 12.962 & $8.2 \mathrm{E}-27$ \\
260 & -2.218 & $7.767 \mathrm{E}+04$ & $7.825 \mathrm{E}+04$ & $1.906 \mathrm{E}-16$ & 12.967 & $2.9 \mathrm{E}-26$ \\
270 & -2.343 & $7.764 \mathrm{E}+04$ & $7.827 \mathrm{E}+04$ & $7.211 \mathrm{E}-16$ & 12.972 & $7.8 \mathrm{E}-25$ \\
280 & -2.459 & $7.760 \mathrm{E}+04$ & $7.830 \mathrm{E}+04$ & $2.479 \mathrm{E}-15$ & 12.977 & $1.7 \mathrm{E}-23$ \\
290 & -2.566 & $7.758 \mathrm{E}+04$ & $7.832 \mathrm{E}+04$ & $7.824 \mathrm{E}-15$ & 12.982 & $2.9 \mathrm{E}-22$ \\
300 & -2.665 & $7.755 \mathrm{E}+04$ & $7.835 \mathrm{E}+04$ & $2.286 \mathrm{E}-14$ & 12.986 & $4.1 \mathrm{E}-21$ \\
310 & -2.756 & $7.752 \mathrm{E}+04$ & $7.838 \mathrm{E}+04$ & $6.231 \mathrm{E}-14$ & 12.991 & $5.0 \mathrm{E}-20$ \\
320 & -2.840 & $7.749 \mathrm{E}+04$ & $7.840 \mathrm{E}+04$ & $1.595 \mathrm{E}-13$ & 12.995 & $5.1 \mathrm{E}-19$ \\
\hline
\end{tabular}

Table 4. Thermodynamic and kinetic properties of ADE2 $\rightarrow$ ADE3

\begin{tabular}{|ccccccc|}
\hline $\mathrm{T}(\mathrm{K})$ & $\triangle \mathrm{S}(\mathrm{J} / \mathrm{K} . \mathrm{mol})$ & $\triangle \mathrm{H}(\mathrm{J} / \mathrm{mol})$ & $\triangle \mathrm{G}(\mathrm{J} / \mathrm{mol})$ & $\mathrm{K}_{\mathrm{P}}$ & $\log _{10}(\mathrm{~A})$ & $\mathrm{k}$ \\
\hline 220 & -0.683 & $-2.455 \mathrm{E}+04$ & $-2.439 \mathrm{E}+04$ & $6.189 \mathrm{E}+05$ & 13.152 & $7.2 \mathrm{E}-07$ \\
230 & -0.742 & $-2.456 \mathrm{E}+04$ & $-2.439 \mathrm{E}+04$ & $3.453 \mathrm{E}+05$ & 13.177 & $5.3 \mathrm{E}-06$ \\
240 & -0.794 & $-2.457 \mathrm{E}+04$ & $-2.438 \mathrm{E}+04$ & $2.022 \mathrm{E}+05$ & 13.201 & $3.3 \mathrm{E}-05$ \\
250 & -0.845 & $-2.458 \mathrm{E}+04$ & $-2.437 \mathrm{E}+04$ & $1.235 \mathrm{E}+05$ & 13.223 & $1.8 \mathrm{E}-04$ \\
260 & -0.897 & $-2.459 \mathrm{E}+04$ & $-2.436 \mathrm{E}+04$ & $7.838 \mathrm{E}+04$ & 13.244 & $8.3 \mathrm{E}-04$ \\
270 & -0.948 & $-2.460 \mathrm{E}+04$ & $-2.435 \mathrm{E}+04$ & $5.142 \mathrm{E}+04$ & 13.265 & $3.5 \mathrm{E}-03$ \\
280 & -0.997 & $-2.462 \mathrm{E}+04$ & $-2.434 \mathrm{E}+04$ & $3.476 \mathrm{E}+04$ & 13.285 & $1.3 \mathrm{E}-02$ \\
290 & -1.046 & $-2.463 \mathrm{E}+04$ & $-2.433 \mathrm{E}+04$ & $2.414 \mathrm{E}+04$ & 13.303 & $4.6 \mathrm{E}-01$ \\
300 & -1.094 & $-2.465 \mathrm{E}+04$ & $-2.432 \mathrm{E}+04$ & $1.717 \mathrm{E}+04$ & 13.321 & $1.5 \mathrm{E}-01$ \\
310 & -1.140 & $-2.466 \mathrm{E}+04$ & $-2.431 \mathrm{E}+04$ & $1.248 \mathrm{E}+04$ & 13.338 & $4.4 \mathrm{E}-01$ \\
320 & -1.186 & $-2.468 \mathrm{E}+04$ & $-2.430 \mathrm{E}+04$ & $9.254 \mathrm{E}+03$ & 13.355 & $1.2 \mathrm{E}+00$ \\
\hline
\end{tabular}

Table 5. Thermodynamic and kinetic properties of GUA1 $\rightarrow$ GUA2

\begin{tabular}{|lcccccc|}
\hline $\mathrm{T}(\mathrm{K})$ & $\triangle \mathrm{S}(\mathrm{J} / \mathrm{K} . \mathrm{mol})$ & $\triangle \mathrm{H}(\mathrm{J} / \mathrm{mol})$ & $\triangle \mathrm{G}(\mathrm{J} / \mathrm{mol})$ & $\mathrm{K}_{\mathrm{P}}$ & $\log _{10}(\mathrm{~A})$ & $\mathrm{k}$ \\
\hline 220 & 7.089 & $5.577 \mathrm{E}+04$ & $5.471 \mathrm{E}+04$ & $1.343 \mathrm{E}-13$ & 13.552 & $3.5 \mathrm{E}-34$ \\
230 & 7.166 & $5.579 \mathrm{E}+04$ & $5.414 \mathrm{E}+05$ & $5.058 \mathrm{E}-13$ & 13.572 & $4.1 \mathrm{E}-32$ \\
240 & 7.237 & $5.581 \mathrm{E}+04$ & $5.407 \mathrm{E}+05$ & $1.706 \mathrm{E}-12$ & 13.590 & $3.2 \mathrm{E}-30$ \\
250 & 7.304 & $5.582 \mathrm{E}+04$ & $5.400 \mathrm{E}+05$ & $5.223 \mathrm{E}-12$ & 13.608 & $1.7 \mathrm{E}-28$ \\
260 & 7.366 & $5.584 \mathrm{E}+04$ & $5.392 \mathrm{E}+05$ & $1.467 \mathrm{E}-11$ & 13.624 & $7.1 \mathrm{E}-27$ \\
270 & 7.424 & $5.586 \mathrm{E}+04$ & $5.385 \mathrm{E}+05$ & $3.820 \mathrm{E}-11$ & 13.639 & $2.2 \mathrm{E}-25$ \\
280 & 7.479 & $5.587 \mathrm{E}+04$ & $5.378 \mathrm{E}+05$ & $9.291 \mathrm{E}-11$ & 13.653 & $5.2 \mathrm{E}-24$ \\
290 & 7.531 & $5.589 \mathrm{E}+04$ & $5.370 \mathrm{E}+05$ & $2.126 \mathrm{E}-10$ & 13.667 & $1.0 \mathrm{E}-22$ \\
300 & 7.581 & $5.590 \mathrm{E}+04$ & $5.363 \mathrm{E}+05$ & $4.604 \mathrm{E}-10$ & 13.680 & $1.6 \mathrm{E}-21$ \\
310 & 7.627 & $5.591 \mathrm{E}+04$ & $5.355 \mathrm{E}+05$ & $9.486 \mathrm{E}-10$ & 13.692 & $2.1 \mathrm{E}-20$ \\
320 & 7.672 & $5.593 \mathrm{E}+04$ & $5.347 \mathrm{E}+05$ & $1.869 \mathrm{E}-09$ & 13.703 & $2.4 \mathrm{E}-19$ \\
\hline
\end{tabular}


Table 6 . Thermodynamic and kinetic properties of GUA1 $\rightarrow$ GUA3

\begin{tabular}{|lcccccc|}
\hline $\mathrm{T}(\mathrm{K})$ & $\triangle \mathrm{S}(\mathrm{J} / \mathrm{K} . \mathrm{mol})$ & $\triangle \mathrm{H}(\mathrm{J} / \mathrm{mol})$ & $\triangle \mathrm{G}(\mathrm{J} / \mathrm{mol})$ & $\mathrm{K}_{\mathrm{P}}$ & $\log _{10}(\mathrm{~A})$ & $\mathrm{k}$ \\
\hline 220 & -2.567 & $8.619 \mathrm{E}+03$ & $9.167 \mathrm{E}+03$ & $6.662 \mathrm{E}-03$ & 12.947 & $1.5 \mathrm{E}-21$ \\
230 & -2.585 & $8.599 \mathrm{E}+03$ & $9.192 \mathrm{E}+03$ & $8.173 \mathrm{E}-03$ & 12.958 & $4.5 \mathrm{E}-20$ \\
240 & -2.599 & $8.594 \mathrm{E}+03$ & $9.218 \mathrm{E}+03$ & $9.857 \mathrm{E}-03$ & 12.968 & $1.0 \mathrm{E}-18$ \\
250 & -2.610 & $8.592 \mathrm{E}+03$ & $9.243 \mathrm{E}+03$ & $1.171 \mathrm{E}-02$ & 12.978 & $1.8 \mathrm{E}-17$ \\
260 & -2.618 & $8.590 \mathrm{E}+03$ & $9.270 \mathrm{E}+03$ & $1.373 \mathrm{E}-02$ & 12.987 & $2.6 \mathrm{E}-16$ \\
270 & -2.624 & $8.588 \mathrm{E}+03$ & $9.296 \mathrm{E}+03$ & $1.590 \mathrm{E}-02$ & 12.996 & $3.0 \mathrm{E}-15$ \\
280 & -2.628 & $8.587 \mathrm{E}+03$ & $9.323 \mathrm{E}+03$ & $1.823 \mathrm{E}-02$ & 13.003 & $3.0 \mathrm{E}-14$ \\
290 & -2.630 & $8.586 \mathrm{E}+03$ & $9.349 \mathrm{E}+03$ & $2.070 \mathrm{E}-02$ & 13.011 & $2.5 \mathrm{E}-13$ \\
300 & -2.631 & $8.586 \mathrm{E}+03$ & $9.376 \mathrm{E}+03$ & $2.331 \mathrm{E}-02$ & 13.018 & $1.8 \mathrm{E}-12$ \\
310 & -2.630 & $8.586 \mathrm{E}+03$ & $9.402 \mathrm{E}+03$ & $2.605 \mathrm{E}-02$ & 13.024 & $1.1 \mathrm{E}-11$ \\
320 & -2.629 & $8.587 \mathrm{E}+03$ & $9.428 \mathrm{E}+03$ & $2.891 \mathrm{E}-02$ & 13.030 & $6.5 \mathrm{E}-11$ \\
\hline
\end{tabular}

Table 7. Thermodynamic and kinetic properties of GUA2 $\rightarrow$ GUA4

\begin{tabular}{|lccclll|}
\hline $\mathrm{T}(\mathrm{K})$ & $\triangle \mathrm{S}(\mathrm{J} / \mathrm{K} . \mathrm{mol})$ & $\triangle \mathrm{H}(\mathrm{J} / \mathrm{mol})$ & $\triangle \mathrm{G}(\mathrm{J} / \mathrm{mol})$ & \multicolumn{1}{l}{$\mathrm{K}_{\mathrm{P}}$} & $\log _{10}(\mathrm{~A})$ & $\mathrm{k}$ \\
\hline 220 & 8.241 & $6.966 \mathrm{E}+03$ & $5.112 \mathrm{E}+03$ & $6.115 \mathrm{E}-02$ & 12.872 & $2.1 \mathrm{E}-07$ \\
230 & 8.317 & $6.942 \mathrm{E}+03$ & $5.029 \mathrm{E}+03$ & $7.210 \mathrm{E}-02$ & 12.888 & $1.6 \mathrm{E}-06$ \\
240 & 8.385 & $6.957 \mathrm{E}+03$ & $4.945 \mathrm{E}+03$ & $8.389 \mathrm{E}-02$ & 12.904 & $9.7 \mathrm{E}-06$ \\
250 & 8.446 & $6.973 \mathrm{E}+03$ & $4.861 \mathrm{E}+03$ & $6.458 \mathrm{E}-02$ & 12.918 & $5.2 \mathrm{E}-05$ \\
260 & 8.500 & $6.986 \mathrm{E}+03$ & $4.776 \mathrm{E}+03$ & $1.098 \mathrm{E}-01$ & 12.932 & $2.5 \mathrm{E}-04$ \\
270 & 8.549 & $6.999 \mathrm{E}+03$ & $4.691 \mathrm{E}+03$ & $1.237 \mathrm{E}-01$ & 12.946 & $1.1 \mathrm{E}-03$ \\
280 & 8.593 & $7.012 \mathrm{E}+03$ & $4.605 \mathrm{E}+03$ & $1.383 \mathrm{E}-01$ & 12.959 & $4.0 \mathrm{E}-03$ \\
290 & 8.633 & $7.023 \mathrm{E}+03$ & $4.519 \mathrm{E}+03$ & $1.535 \mathrm{E}-01$ & 12.972 & $1.4 \mathrm{E}-02$ \\
300 & 8.669 & $7.033 \mathrm{E}+03$ & $4.433 \mathrm{E}+03$ & $1.691 \mathrm{E}-01$ & 12.984 & $4.5 \mathrm{E}-02$ \\
310 & 8.701 & $7.043 \mathrm{E}+03$ & $4.346 \mathrm{E}+03$ & $1.852 \mathrm{E}-01$ & 12.995 & $1.3 \mathrm{E}-01$ \\
320 & 8.731 & $7.053 \mathrm{E}+03$ & $4.259 \mathrm{E}+03$ & $2.018 \mathrm{E}-01$ & 13.006 & $3.7 \mathrm{E}-01$ \\
\hline
\end{tabular}

Table 8 . Thermodynamic and kinetic properties of GUA3 $\rightarrow$ GUA5

\begin{tabular}{|lcccccc|}
\hline $\mathrm{T}(\mathrm{K})$ & $\triangle \mathrm{S}(\mathrm{J} / \mathrm{K} . \mathrm{mol})$ & $\triangle \mathrm{H}(\mathrm{J} / \mathrm{mol})$ & $\triangle \mathrm{G}(\mathrm{J} / \mathrm{mol})$ & $\mathrm{K}_{\mathrm{P}}$ & $\log _{10}(\mathrm{~A})$ & $k$ \\
\hline 220 & 12.459 & $1.409 \mathrm{E}+05$ & $1.382 \mathrm{E}+05$ & $1.550 \mathrm{E}-33$ & 13.178 & $1.3 \mathrm{E}-38$ \\
230 & 12.693 & $1.410 \mathrm{E}+05$ & $1.381 \mathrm{E}+05$ & $4.419 \mathrm{E}-32$ & 13.192 & $2.2 \mathrm{E}-36$ \\
240 & 12.922 & $1.410 \mathrm{E}+05$ & $1.380 \mathrm{E}+05$ & $9.543 \mathrm{E}-31$ & 13.205 & $2.4 \mathrm{E}-34$ \\
250 & 13.111 & $1.411 \mathrm{E}+05$ & $1.378 \mathrm{E}+05$ & $1.613 \mathrm{E}-29$ & 13.217 & $1.9 \mathrm{E}-32$ \\
260 & 13.298 & $1.411 \mathrm{E}+05$ & $1.376 \mathrm{E}+05$ & $2.196 \mathrm{E}-28$ & 13.229 & $1.0 \mathrm{E}-30$ \\
270 & 13.475 & $1.412 \mathrm{E}+05$ & $1.375 \mathrm{E}+05$ & $2.465 \mathrm{E}-27$ & 13.239 & $4.2 \mathrm{E}-29$ \\
280 & 13.640 & $1.412 \mathrm{E}+05$ & $1.374 \mathrm{E}+05$ & $2.331 \mathrm{E}-26$ & 13.250 & $1.3 \mathrm{E}-27$ \\
290 & 13.796 & $1.413 \mathrm{E}+05$ & $1.373 \mathrm{E}+05$ & $1.888 \mathrm{E}-25$ & 13.259 & $3.3 \mathrm{E}-26$ \\
300 & 13.944 & $1.413 \mathrm{E}+05$ & $1.371 \mathrm{E}+05$ & $1.332 \mathrm{E}-24$ & 13.268 & $6.5 \mathrm{E}-25$ \\
310 & 14.084 & $1.414 \mathrm{E}+05$ & $1.370 \mathrm{E}+05$ & $8.282 \mathrm{E}-24$ & 13.277 & $1.1 \mathrm{E}-23$ \\
320 & 14.217 & $1.414 \mathrm{E}+05$ & $1.368 \mathrm{E}+05$ & $4.598 \mathrm{E}-23$ & 13.285 & $1.5 \mathrm{E}-22$ \\
\hline
\end{tabular}


Table 9. Thermodynamic and kinetic properties of GUA3 $\rightarrow$ GUA7

\begin{tabular}{|c|c|c|c|c|c|c|}
\hline \multicolumn{3}{|c|}{$\mathrm{T}(\mathrm{K}) \triangle \mathrm{S}(\mathrm{J} / \mathrm{K} \cdot \mathrm{mol}) \triangle \mathrm{H}(\mathrm{J} / \mathrm{mol})$} & \multirow{2}{*}{$\begin{array}{r}\mathrm{G}(\mathrm{J} / \mathrm{mol}) \\
8.735 \mathrm{E}+04\end{array}$} & \multirow{2}{*}{$\frac{\mathrm{K}_{\mathrm{P}}}{1.826 \mathrm{E}-21}$} & \multirow{2}{*}{$\frac{\log _{10}(\mathrm{~A})}{13.347}$} & \multirow{2}{*}{$\frac{\mathrm{k}}{2.6 \mathrm{E}-38}$} \\
\hline 220 & 5.246 & $8.850 \mathrm{E}+04$ & & & & \\
\hline 230 & 5.254 & $8.850 \mathrm{E}+04$ & $8.729 \mathrm{E}+04$ & $1.497 \mathrm{E}-20$ & 13.362 & 4.4E-36 \\
\hline 240 & 5.260 & $8.850 \mathrm{E}+04$ & $8.724 \mathrm{E}+04$ & $1.030 \mathrm{E}-19$ & 13.375 & $4.9 \mathrm{E}-34$ \\
\hline 250 & 5.263 & $8.850 \mathrm{E}+04$ & $8.719 \mathrm{E}+04$ & $6.069 \mathrm{E}-19$ & 13.388 & 3.7E-32 \\
\hline 260 & 5.267 & $8.850 \mathrm{E}+04$ & $8.714 \mathrm{E}+04$ & $3.121 \mathrm{E}-18$ & 13.399 & $2.0 \mathrm{E}-30$ \\
\hline 270 & 5.269 & $8.851 \mathrm{E}+04$ & $8.709 \mathrm{E}+04$ & $1.220 \mathrm{E}-17$ & 13.410 & $8.2 \mathrm{E}-29$ \\
\hline 280 & 5.272 & $8.851 \mathrm{E}+04$ & $8.703 \mathrm{E}+04$ & $5.813 \mathrm{E}-17$ & 13.420 & $2.5 \mathrm{E}-27$ \\
\hline 290 & 5.274 & $8.851 \mathrm{E}+04$ & $8.698 \mathrm{E}+04$ & $2.157 \mathrm{E}-16$ & 13.430 & $6.2 \mathrm{E}-26$ \\
\hline 300 & 5.278 & $8.851 \mathrm{E}+04$ & $8.693 \mathrm{E}+04$ & $7.331 \mathrm{E}-16$ & 13.439 & $1.2 \mathrm{E}-24$ \\
\hline 310 & 5.281 & $8.851 \mathrm{E}+04$ & $8.687 \mathrm{E}+04$ & $2.303 \mathrm{E}-15$ & 13.448 & $2.0 \mathrm{E}-23$ \\
\hline 320 & 5.285 & $8.851 \mathrm{E}+04$ & $8.682 \mathrm{E}+04$ & $6.735 \mathrm{E}-15$ & 13.456 & $2.8 \mathrm{E}-22$ \\
\hline
\end{tabular}

Table 10. Thermodynamic and kinetic properties of GUA5 $\rightarrow$ GUA6

\begin{tabular}{|llllllll|}
\hline $\mathrm{T}(\mathrm{K})$ & $\triangle \mathrm{S}(\mathrm{J} / \mathrm{K} . \mathrm{mol}) \triangle \mathrm{H}(\mathrm{J} / \mathrm{mol})$ & $\triangle \mathrm{G}(\mathrm{J} / \mathrm{mol})$ & $\mathrm{K}_{\mathrm{P}}$ & \multicolumn{2}{c|}{$\log _{10}(\mathrm{~A})$} & $\mathrm{k}$ \\
\hline 220 & -5.993 & $-2.887 \mathrm{E}+04$ & $-2.755 \mathrm{E}+04$ & $3.477 \mathrm{E}+06$ & 12.736 & $1.5 \mathrm{E}-04$ & \\
230 & -6.126 & $-2.890 \mathrm{E}+04$ & $-2.749 \mathrm{E}+04$ & $1.750 \mathrm{E}+06$ & 12.750 & $8.2 \mathrm{E}-04$ & \\
240 & -6.252 & $-2.893 \mathrm{E}+04$ & $-2.743 \mathrm{E}+04$ & $9.321 \mathrm{E}+05$ & 12.763 & $3.9 \mathrm{E}-03$ & \\
250 & -6.370 & $-2.896 \mathrm{E}+04$ & $-2.737 \mathrm{E}+04$ & $5.218 \mathrm{E}+05$ & 12.776 & $1.6 \mathrm{E}-02$ & \\
260 & -6.482 & $-2.899 \mathrm{E}+04$ & $-2.730 \mathrm{E}+04$ & $3.053 \mathrm{E}+05$ & 12.789 & $6.0 \mathrm{E}-02$ & \\
270 & -6.587 & $-2.901 \mathrm{E}+04$ & $-2.724 \mathrm{E}+04$ & $1.857 \mathrm{E}+05$ & 12.802 & $2.1 \mathrm{E}-01$ & \\
280 & -6.687 & $-2.904 \mathrm{E}+04$ & $-2.717 \mathrm{E}+04$ & $1.170 \mathrm{E}+05$ & 12.814 & $6.4 \mathrm{E}-01$ & \\
290 & -6.781 & $-2.907 \mathrm{E}+04$ & $-2.710 \mathrm{E}+04$ & $7.611 \mathrm{E}+04$ & 12.826 & $1.8 \mathrm{E}+00$ & \\
300 & -6.871 & $-2.909 \mathrm{E}+04$ & $-2.703 \mathrm{E}+04$ & $5.091 \mathrm{E}+04$ & 12.837 & $5.0 \mathrm{E}+00$ & \\
310 & -6.956 & $-2.912 \mathrm{E}+04$ & $-2.696 \mathrm{E}+04$ & $3.494 \mathrm{E}+04$ & 12.849 & $1.3 \mathrm{E}+01$ & \\
320 & -7.036 & $-2.915 \mathrm{E}+04$ & $-2.689 \mathrm{E}+04$ & $2.454 \mathrm{E}+04$ & 12.859 & $3.0 \mathrm{E}+01$ & \\
\hline
\end{tabular}

Table 11. Thermodynamic and kinetic properties of GUA7 $\rightarrow$ GUA8

\begin{tabular}{|lcccccc|}
\hline $\mathrm{T}(\mathrm{K})$ & $\triangle \mathrm{S}(\mathrm{J} / \mathrm{K} . \mathrm{mol})$ & $\triangle \mathrm{H}(\mathrm{J} / \mathrm{mol})$ & $\triangle \mathrm{G}(\mathrm{J} / \mathrm{mol})$ & $\mathrm{K}_{\mathrm{P}}$ & $\log _{10}(\mathrm{~A})$ & $\mathrm{k}$ \\
\hline 220 & 1.688 & $2.573 \mathrm{E}+04$ & $2.535 \mathrm{E}+04$ & $9.578 \mathrm{E}-07$ & 13.075 & $4.8 \mathrm{E}-13$ \\
230 & 1.767 & $2.574 \mathrm{E}+04$ & $2.533 \mathrm{E}+04$ & $1.766 \mathrm{E}-06$ & 13.097 & $6.4 \mathrm{E}-12$ \\
240 & 1.842 & $2.576 \mathrm{E}+04$ & $2.531 \mathrm{E}+04$ & $3.094 \mathrm{E}-06$ & 13.119 & $6.9 \mathrm{E}-11$ \\
250 & 1.912 & $2.577 \mathrm{E}+04$ & $2.530 \mathrm{E}+04$ & $5.186 \mathrm{E}-06$ & 13.139 & $6.1 \mathrm{E}-10$ \\
260 & 1.979 & $2.579 \mathrm{E}+04$ & $2.528 \mathrm{E}+04$ & $8.356 \mathrm{E}-06$ & 13.159 & $4.7 \mathrm{E}-09$ \\
270 & 2.042 & $2.581 \mathrm{E}+04$ & $2.526 \mathrm{E}+04$ & $1.300 \mathrm{E}-05$ & 13.178 & $3.0 \mathrm{E}-08$ \\
280 & 2.101 & $2.582 \mathrm{E}+04$ & $2.524 \mathrm{E}+04$ & $1.960 \mathrm{E}-05$ & 13.196 & $1.7 \mathrm{E}-07$ \\
290 & 2.157 & $2.584 \mathrm{E}+04$ & $2.521 \mathrm{E}+04$ & $2.874 \mathrm{E}-05$ & 13.213 & $8.8 \mathrm{E}-07$ \\
300 & 2.211 & $2.586 \mathrm{E}+04$ & $2.519 \mathrm{E}+04$ & $4.109 \mathrm{E}-05$ & 13.230 & $4.0 \mathrm{E}-06$ \\
310 & 2.261 & $2.587 \mathrm{E}+04$ & $2.517 \mathrm{E}+04$ & $5.741 \mathrm{E}-05$ & 13.246 & $1.7 \mathrm{E}-05$ \\
320 & 2.309 & $2.589 \mathrm{E}+04$ & $2.515 \mathrm{E}+04$ & $7.857 \mathrm{E}-05$ & 13.262 & $6.3 \mathrm{E}-05$ \\
\hline
\end{tabular}




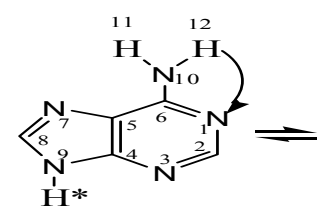

ADE 1<smiles>[H]/N=c1/c2nc[nH]c2ncn1C#C</smiles>

ADE2

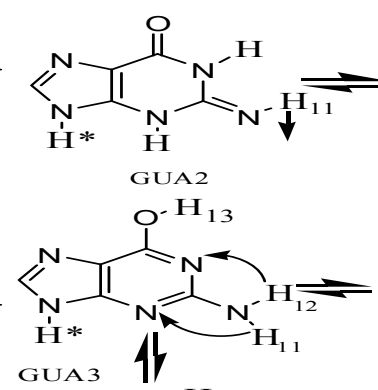

ADE3<smiles>N=c1[nH]c(=O)c2nc[nH]c2[nH]1</smiles><smiles></smiles>
GuAs<smiles>NC=[W]1N=C(O)c2nc[nH]c2N1</smiles>
$\dot{H} * \dot{H}_{1}$ GUA7 外<smiles></smiles>
GUAG<smiles></smiles>
GAU 8

Figure 1. Isomers and isomerization processes of adenine and guanine

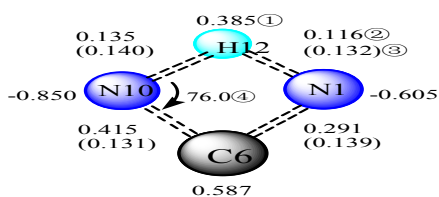

TS-A12, $1907 \mathrm{i}$

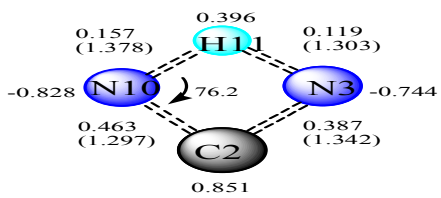

TS-G24, $931 \mathrm{i}$
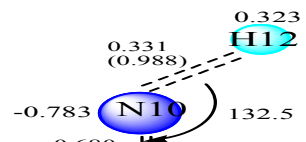

(1.263):

$0.747 \mathrm{C2}$

TS-G24, $931 \mathrm{i}$

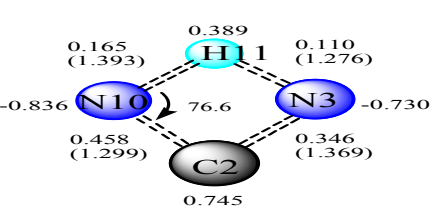

TS-G37, 1905 i
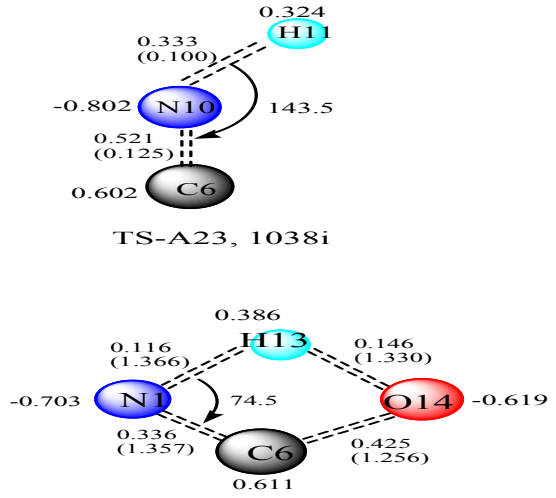

TS-G13, 1865 i

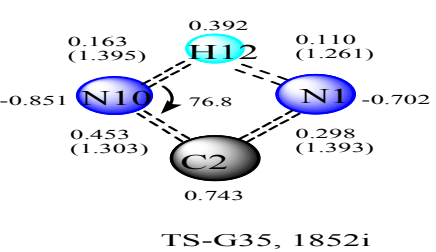

TS-G35, 1852 i
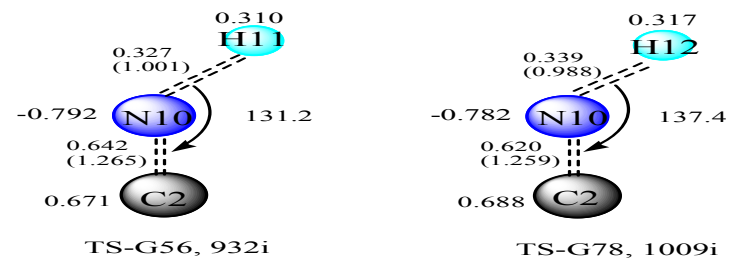

Figure 2. Parameters of the main parts of transition states and their imaginary frequencies (1)charge (2)electron population (3)bond length (4)bond angle) 


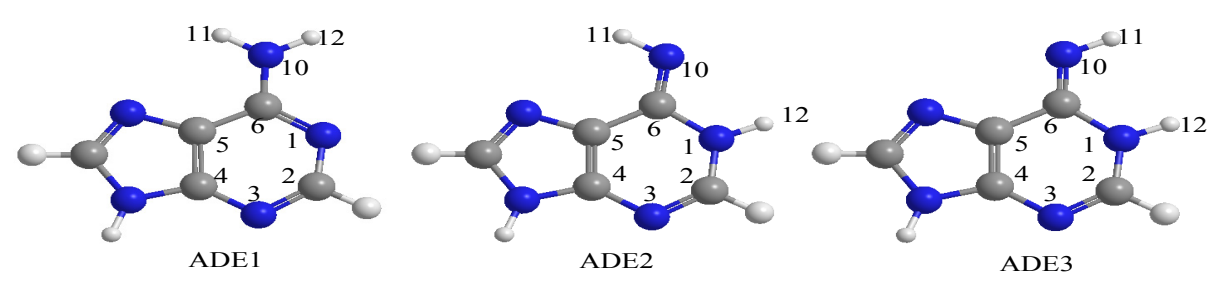

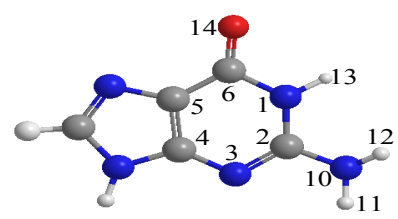

GUA1

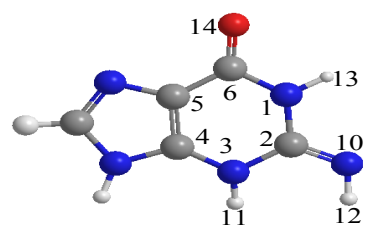

GUA4

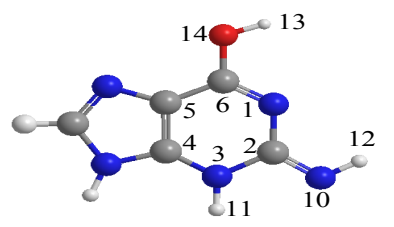

GUA7

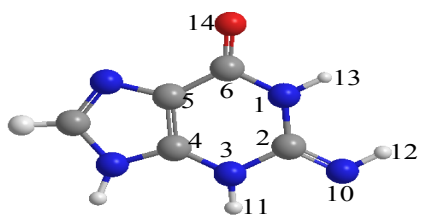

GUA2

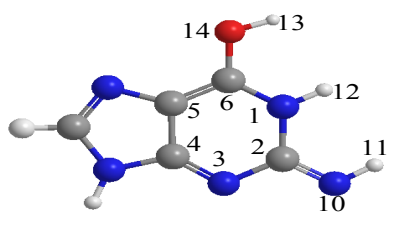

GUA5

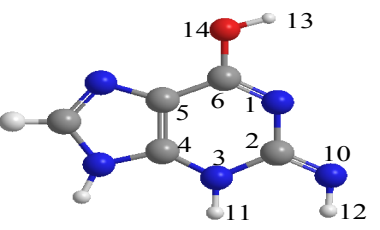

GUA8

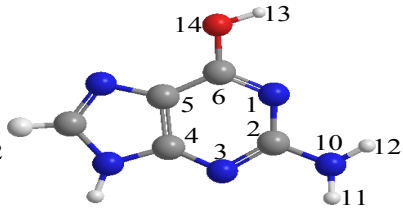

GUA3

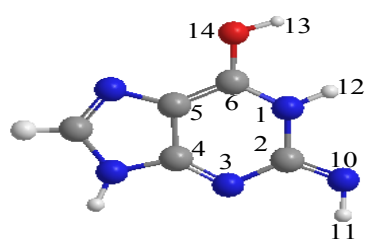

GUA6

Figure 3 . The structures of the isomers of adenine and guanine

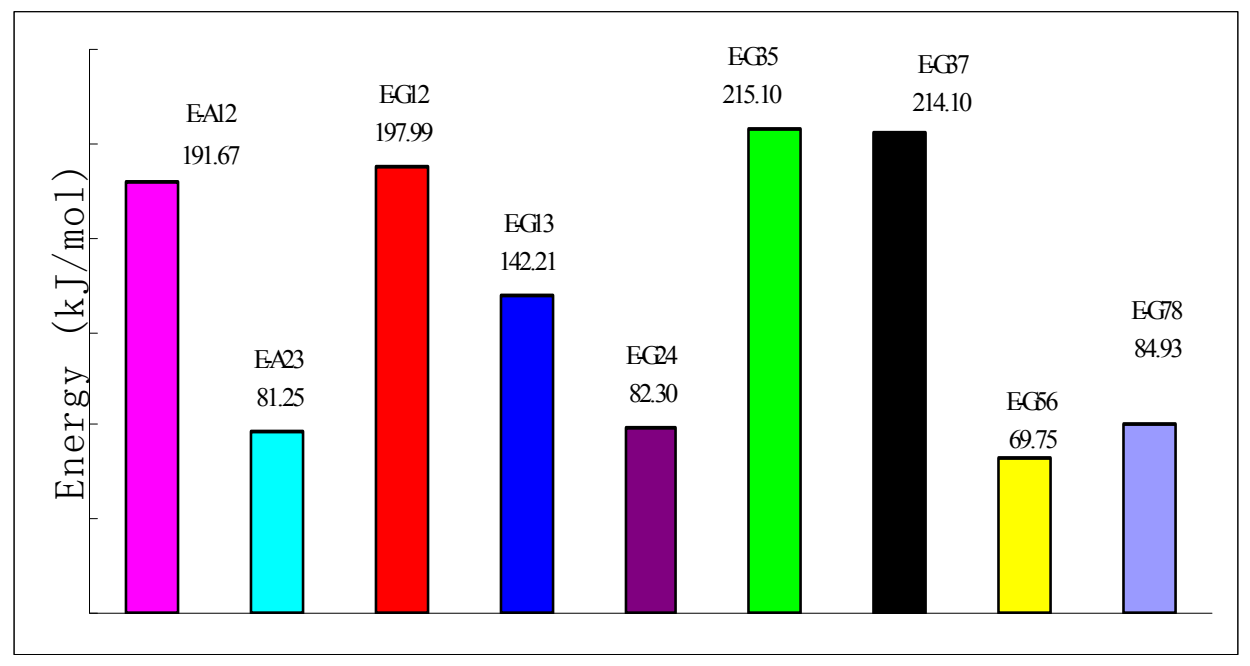

Figure 4. Activation energies of the isomerization processes of adenine and guanine 
ADE1-ADE2

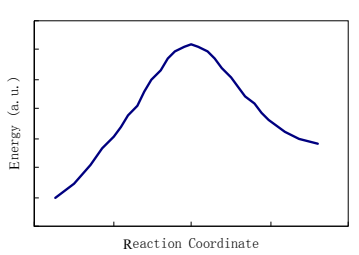

Reaction Coordinate

GUA1-GIA3

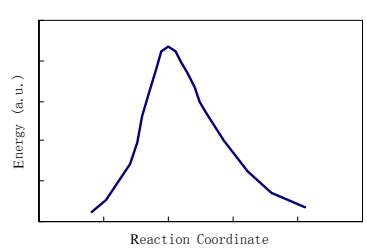

GUA3-GLA7

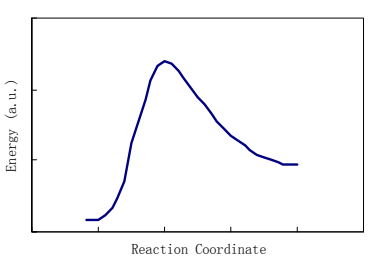

ADE2-ADE 3

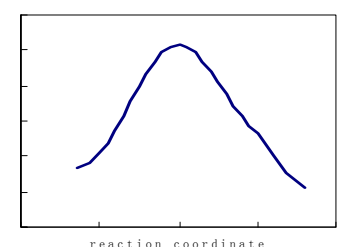

GUA2-GUA4

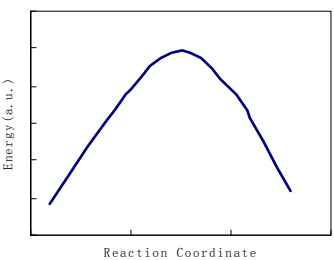

Reaction Coordinate

GUA5-GUA6

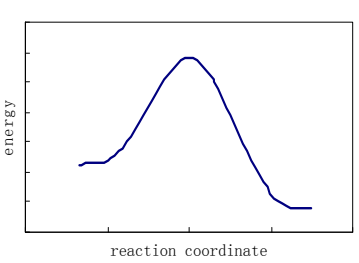

GUA1-GUA2

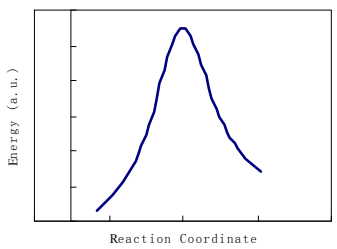

GLA3-GIA5

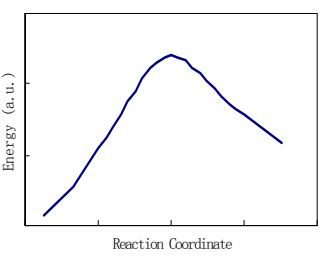

GUA7-GUAS

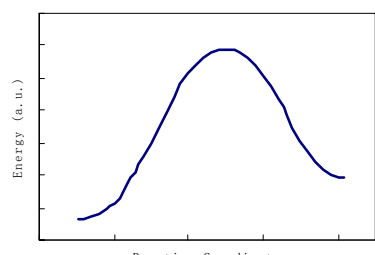

Figure 5. IRC curves of the isomerization processes of adenine and guanine

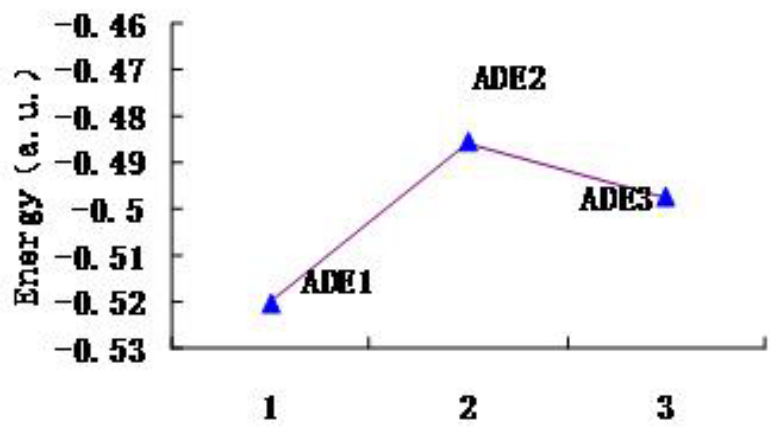

Figure 6. Energies of three adenine isomers

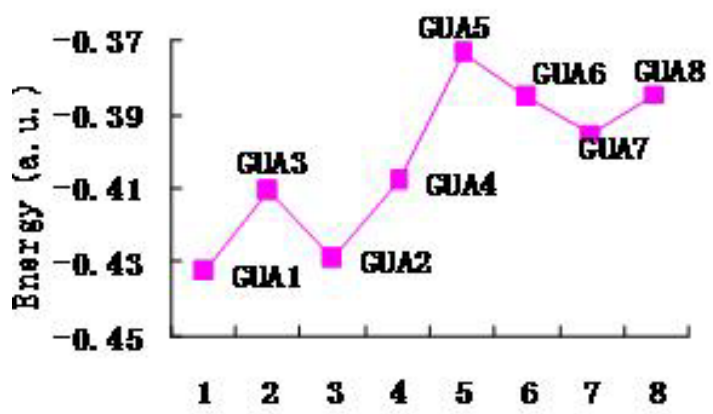

Figure 7. Energies of eight guanine isomers 